https://doi.org/10.46344/JBINO.2020.v09i06.13

\title{
ESTIMATION OF STATURE FROM ANTHROPOMETRIC MEASUREMENT OF CHEST CIRCUMFERENCE AND WEIGHT OF THE BODY AMONGST INDIGENOUS TEENAGERS OF BEKWARRA AND OBUDU LOCAL GOVERNMENT OF CROSS RIVER STATE, NIGERIA
}

\author{
"Mba Christian Ejuiwa, "Abireh Ifeanacho Ezeteonu, "Ozioko Onyinye Mary, "Ozioko Uche Sabastine and Ede \\ Emmanuel
}

*Department of Anatomy, Faculty of Basic medical sciences, Enugu State University of Science \&Technology, Enugu State, Nigeria.

E-mail : dogo4all@yahoo.com

\begin{abstract}
Background: Human stature is one of the prime physical attributes employed in assessing growth,nutrition, calculating body surface area and in disaster victim identification .Materials and methods: The study comprises a total of two hundred (200) teenagers, (100 males and 100 females), comprising of hundred (100) subjects each from Bekwarra and Obudu local government area of Cross River State within 13-19 years old, were selected randomly. Their height, weight and chest circumference were measured. Results: Findings reveals phenotypical differences with reference to chest circumference exists. Bekwarra male subjects of our cohort are significantly taller $(p<0.05)$ and also has higher values in chest circumference and weight compare to Bekwarra females, the same inference is observed when comparing males and females in Obudu subjects except in chest circumference were females have observed higher values compared to males. It was observed that Obudu males and females have higher chest circumference and weight values than the Bekwarra subjects in our cohort. All chest circumference measured in males in Bekwarra and Obudu correlated statistically with stature. Conclusion: Chest circumference can be used to estimate the stature of an individual in forensic investigations and help to compare anthropometric parameters or body dimension of other Nigeria ethnic groups.
\end{abstract}

Key words: Stature, weight and chest circumference. 


\section{INTRODUCTION}

Anthropometry refers to the study of dimensions of different parts of the body which shows variations according to age, sex and race.).(Deopa et al., 2013).The field of anthropometry covers a variety of measurements of the human body such as Weight, stature (height when standing), reclined length, skin pleats, circumference (head, waist, etc.), length of extremities and widths (shoulders, wrist, etc.) (Pate et al,2012, Vicente, 2015; Norton and Tim, 2012). This study was meant to help provide an estimated database on forensic investigations as to how the circumference of the chest of an individual can be used to estimate such individual's height.

Man has shown his superiority over other bipedal animals by making anthropometric comparisons to validate his claims as a highly modified animal over the years. These anthropometric dimensions vary in individuals of different ethnicities, time periods, age, gender, etc. (Alonso, 2006).

The chest cavity is bounded anteriorly and posteriorly by the chest wall and below by the diaphragm. It extends upward into the root of the neck about one fingerbreadth above the clavicle on each side. The diaphragm, which is a very thin muscle, is the only structure (apart from the pleura and the peritoneum) that separates the chest from the abdominal viscera.

The chest cavity can be divided into a median partition, called the mediastinum, and the laterally placed pleurae and lungs.Its walls include muscles, ribs, the skin, the mammary glands of the breast, and fascia covering its anteriolateral and posterior aspects (Snell et al., 2006)Stature or a person's natural height is one of the most important parameter to determine physical characteristics. In recent studies of forensic science,stature estimation has been carried out from different body dimensions like hands and phalanges length(Zaheret al.2011,)handprints(Krishan et al 2015 )foot prints (Kanchas et al 2013) to estimate the relationship between body dimensions, stature however is the major predictor of other body parts(Oyewloeet al.,2010). Anthropometrical parameterssuch as Stature, chest circumference weight, midarm circumference (MRC), body mass index, head circumference, thigh circumference, triceps skin fold have been found to exhibit consistent ratios among themselves relative to the total body height.-

Human stature is one of the prime physical attributes employed in ascertaining the identification of unknown mutilated bodies found in crime scenes(Kanchanet al.,2011), it is also a fundamental characteristics employed in assessing growth nutrition, calculating body surface area andin disaster victim identification (Oria et al.,2016).The problem of correlating various metric traits of skeletal remains with the stature of an individual has confronted scientists for a long time. The problem is accentuated by the fact that a number of common disease or 
deformities of the vertebral column make it difficult to accurately measure standing height in many patients (Auyeung et al., 2009).

The development of height is a very sensitive trait which depends on varying factors such as sex, age, race, body composition, socioeconomic status and secular happenings. Although, many formulae for stature estimation have been proposed, there is concern regarding the accuracy of the use of population specific formulae on other human populations (Williams et al.2000, Duyer et al., 2006)hence application of one specific formula for a particular population for other groups is unacceptable as different regions possess their peculiar characteristics(Krishan et al .,2015). Thus, there is need for tribe, sex, and age specific stature estimation formulae (Krishan, 2007)

Variety of long bones have been employed for stature estimation in different race(Jadav et al., 2004; Krishan, 2007)but few studies have explored the relationship between stature, weight and chest circumference .Hence, this study was designed to elucidate and compare the norms for stature, chest circumference and weight, and to propose population and gender specific regression models for stature estimation ofBekwarra and Obudu indigenes in Cross River State of Nigeria.

\section{MATERIALS AND METHODS}

\section{Study Design}

This study was carried out in Bekwarra and Obudu Local Government Areas of Cross
River State, Nigeria, among randomly selected indigenous teenagers of Bekwarra and Obudu. The study cohort comprises a total of two hundred (200) teenagers (100 males and 100 females), comprising of hundred (100) subjects each from Bekwarra and Obudu local government area of Cross River State, who fall within the age group of 13-19 years, were selected randomly.Participants invited for this research were healthy without any form of obvious congenital standing inability like scoliosis, kyphosis or chest defects.

\section{Materials Used}

Weighing scale (P.M hana (HK) Ltd HongKong September 2015, reg. No SON/MPR/ME/127) for measuring weight

* Secastadiometercaliberated in $\mathrm{cm}$

* A plastic measuring tape calibrated in $\mathrm{cm}$ for measuring chest circumference

* $\quad$ A pen and notebook
- Spss software application

\section{Stature Measurement}

Measurement of Stature -

Each subject was made to stand erect and height was measured using a stadiometer.

WEIGHT: Weight of each subject was checked using weighing scale. The subjects removed excess materials like shoes, belt, watche.t.c 

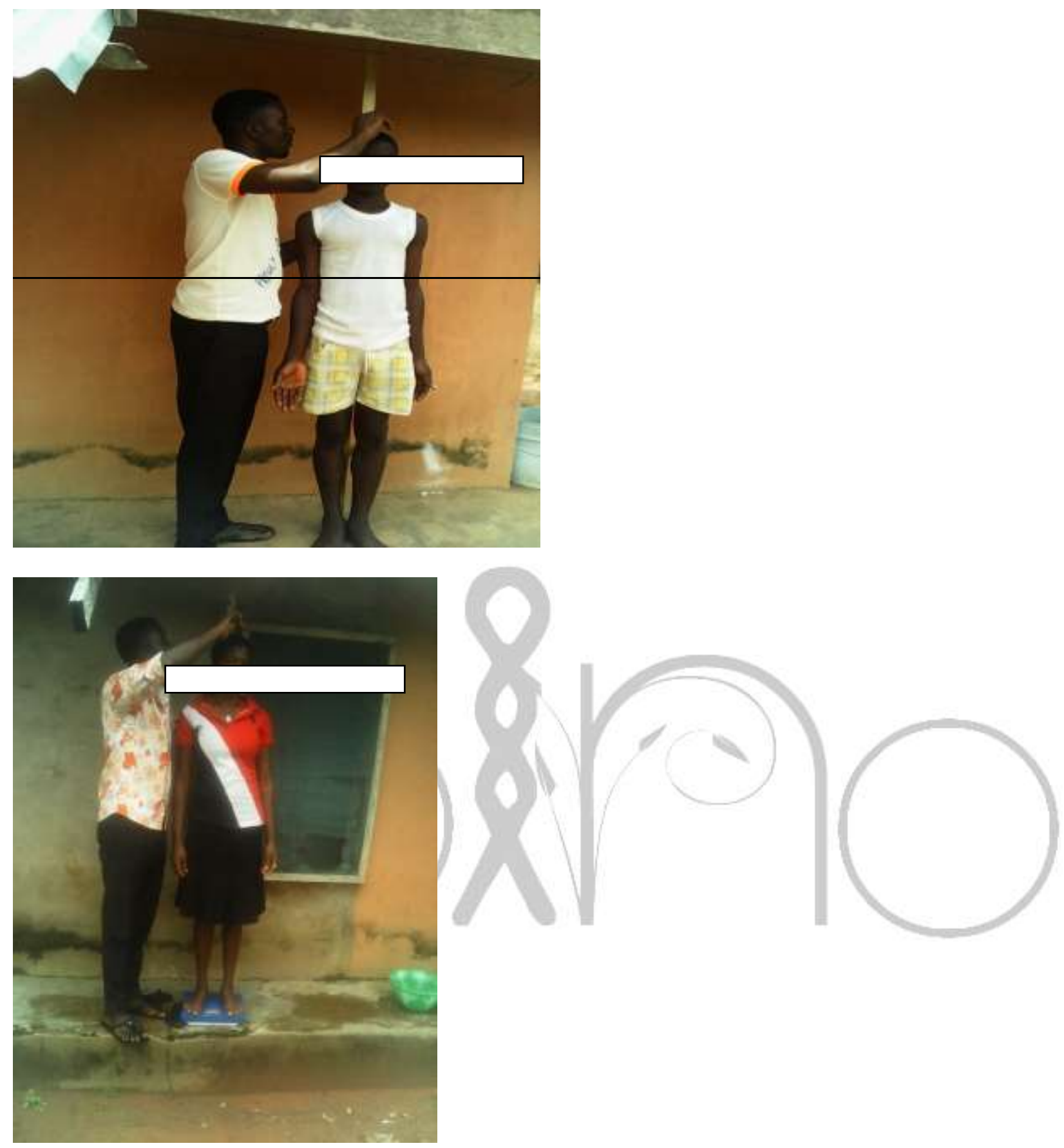

Figure 1: Experimental measurement of height in male and female in Bekwarra and Obudu.

\section{CHEST CIRCUMFERENCE MEASUREMENT}

All the measurements, for chest circumference were taken at the level of the nipple (the widest part at the level the armpit) with the plastic tape running under the armpit. 


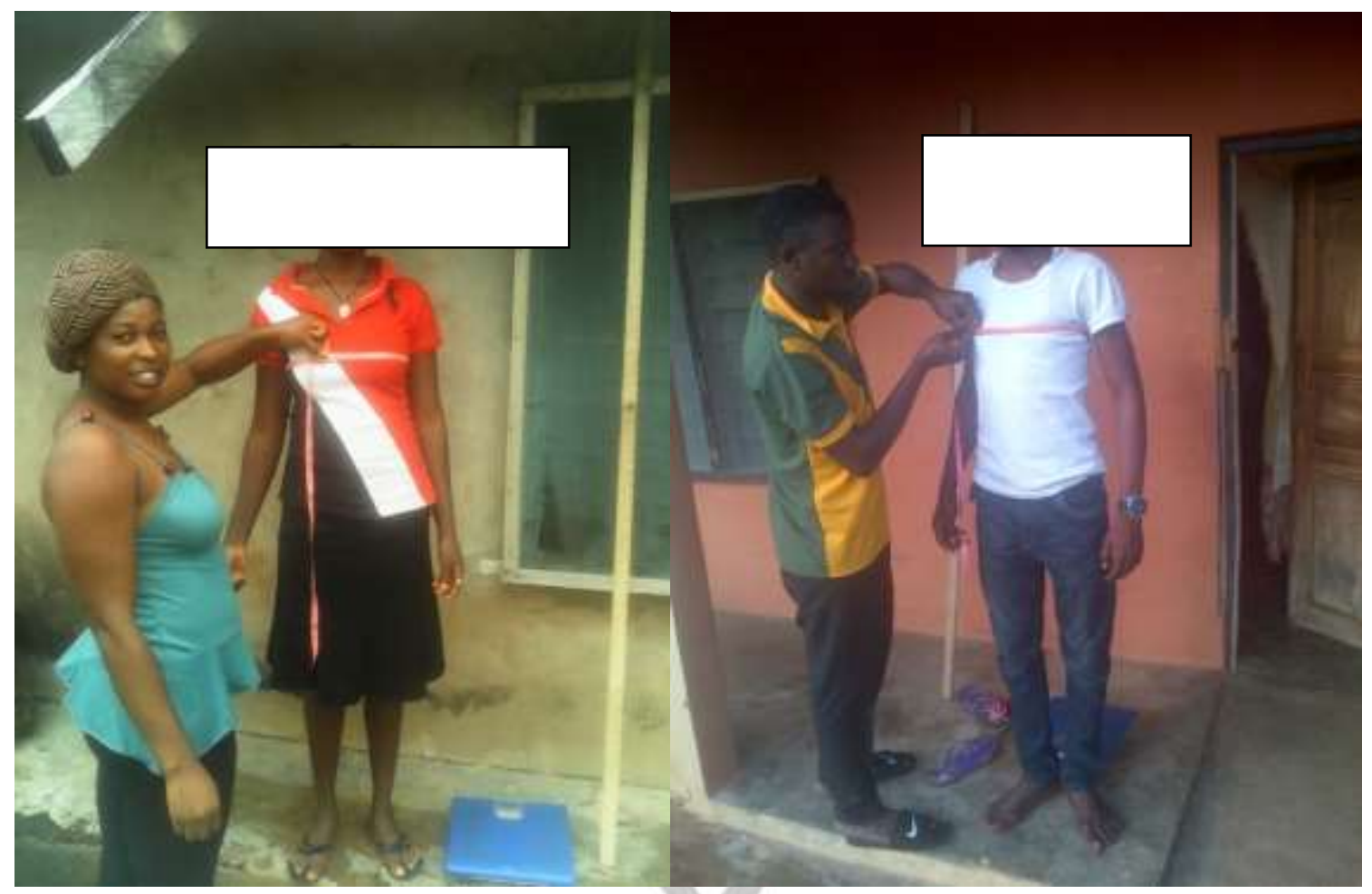

Figure 2 : Experimental measurement of chest circumference in male and female subject

\section{WEIGHT MEASUREMENT}

Weight measurement was taken using weighing scale. The subjects were asked to remove any heavy garments (jacket, coat etc) and shoes. The subject was on the centre of the platform, reading was taken in both males and females

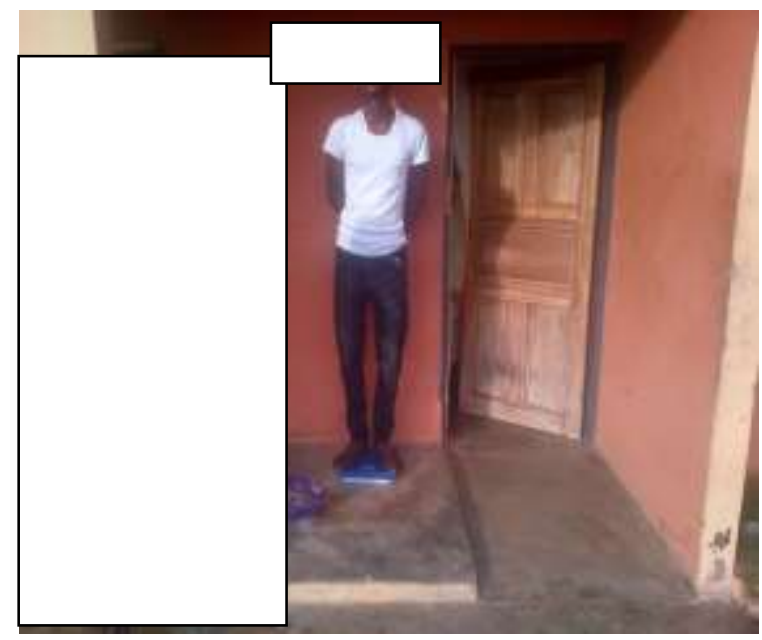

Figure 3: Experimental measurement of weight in male subjects 2020 November Edition | www.jbino.com | Innovative Association 


\section{RESULTS}

The data obtained was subjected to series of analysis usingstatistical package for social sciences( SPSS) software version 20.Descriptive statistics was employed and presented as Mean $\pm S D$. Student t-test was used equally to ascertain sexual dimorphism at $P<0.01$. Pearson's correlation coefficient ( $r$ ) was used to examine the relationship between various anthropometric parameters measured. Also linear regression was performed and linear regression equation formulas were derived using MS word excel window 7 for the prediction of stature using anthropometric parameters.

The parameters that were measured from each volunteer were stature (height), chest circumference and weight.

Table 1: Showing statistical difference in parameters studied between males in Bekwarra and Obudu and, females in Bekwarra andObudu.

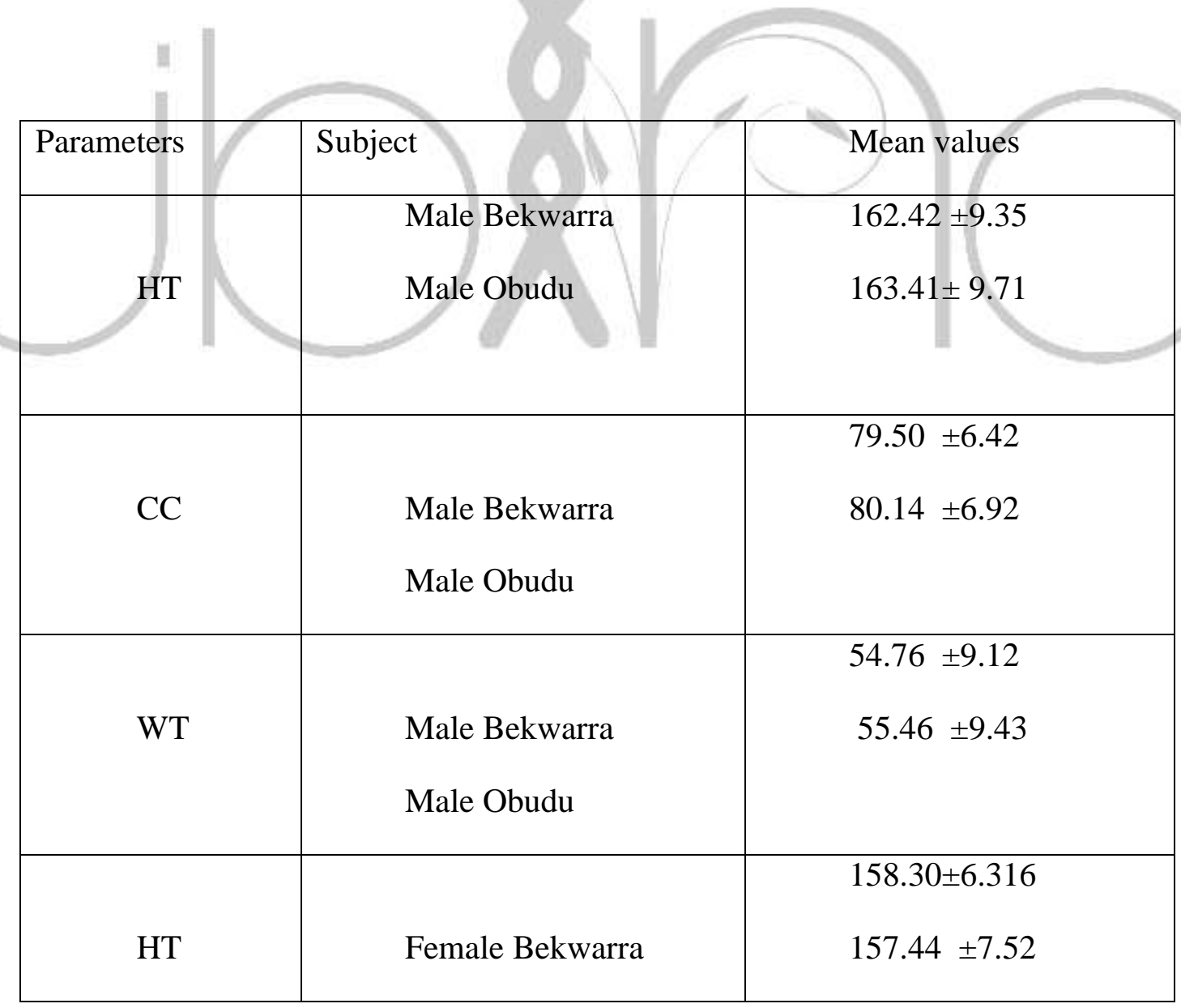




\begin{tabular}{|c|c|c|}
\hline & Female Obudu & \\
\hline $\mathrm{CC}$ & $\begin{array}{l}\text { Female Bekwarra } \\
\text { Female Obudu }\end{array}$ & $\begin{array}{l}76.91 \pm 7.13^{\mathrm{a}} \\
86.66 \pm 4.88^{\mathrm{a}}\end{array}$ \\
\hline WT & $\begin{array}{l}\text { Female Bekwarra } \\
\text { Female Obudu }\end{array}$ & $\begin{array}{l}52.22 \pm 6.63 \\
53.60 \pm 7.22\end{array}$ \\
\hline
\end{tabular}

Values with similar subscripts are statistically significant at $\mathbf{P}<0.05$

Table 2: Correlation between the stature and various parameters studied in Male and Female in Bekwarra and Obudu ** show high correlation between the parameters, while values without ** do not correlate significantly $P<0.01$

\begin{tabular}{|l|c|c|c|c|}
\hline Parameters & Male Bekwarra & $\begin{array}{l}\text { Female } \\
\text { Bekwarra }\end{array}$ & Male Obudu & Female \\
Obudu \\
\hline CC $(\mathrm{cm}) \mathrm{R}$ & $0.755^{* *}$ & 0.090 & $0.772^{* *}$ & -0.076 \\
\hline WT $(\mathrm{kg}) \mathrm{R}$ & $0.916^{* *}$ & $0.492^{* *}$ & $0.788^{* *}$ & $0.363^{* *}$ \\
\hline
\end{tabular}

$\mathbf{P}<0.01$ (** correlation is statistically significant)

Table 1-2 of this study shows that males are significantly taller $(p<0.05)$ than females. The Bekwarra's males values of chest circumference and weight are not significant but males have higher values than females (table 1) while the Obudu's females values of chest circumference are significantly higher than the males while the males weight are higher than that of the females. The present study shows that males subjects of our cohort are significantly taller $(\mathrm{p}<0.05)$ and also has higher values in chest circumference and weight compare to the females in Bekwarra as shown in table 1 and 2, the same inference is observed when comparing males and females in Obudu subjects except in chest circumference were females haveobserved higher values compared to males. 
Table 3: A predictive linear regression equations of stature $(\mathrm{cm})$ in males $n=100$ and females $n=100$ from the parameters studied in males and females in Bekwarra and Obudu

\begin{tabular}{|l|l|}
\hline Parameters & Linear regression equation \\
\hline MALE IN BEK. STATURE $(\mathrm{CC})$ & $75.039+(1.099 \times \mathrm{CC}) \pm 10.973$ \\
\hline MALE IN BEK. STATURE $(\mathrm{WT})$ & $111.009+(0.939 \times$ weight $) \pm 3.299$ \\
\hline FEMALE IN BEK. STATURE $(\mathrm{CC})$ & $152.1629+(0.080 \times \mathrm{CC}) \pm 9.842$ \\
\hline FEMALE IN BEK. STATURE $(\mathrm{WT})$ & $133.7939+(0.469 \times$ Weight $) \pm 6.301$ \\
\hline MALE IN OBUDU STATURE $(\mathrm{CC})$ & $76.481+(1.085 \times \mathrm{CC}) \pm 10.359$ \\
\hline MALE IN OBUDU STATURE $(\mathrm{WT})$ & $118.415+(0.811 \times \mathrm{Weight}) \pm 5.148$ \\
\hline FEMALE IN OBUDUSTATURE(CC) & $167.633+(-0.118 \times \mathrm{CC}) \pm 19.219$ \\
\hline FEMALE IN OBUDUSTATURE(WT) & $137.166+(0.378 \times$ Weight $) \pm 7.573$ \\
\hline
\end{tabular}

Table 3 represent comparisons in values of the male parameters in both Obudu and Bekwarra in this present study it was observed that Obudu males and females have higher chest circumference and weight values than the Bekwarra subjects in our cohort. 
Table 4: Mean of difference between observed stature and estimated stature parameters

\begin{tabular}{|l|l|l|}
\hline \multicolumn{1}{|c|}{ Parameters } & \multicolumn{1}{|c|}{$\begin{array}{c}\text { Estimated values } \\
\text { for stature }\end{array}$} & Mean stature \\
\hline MALE IN BEK. STATURE (CC) & $80.0 \pm 10.9$ & 86.1 \\
\hline MALE IN BEK. STATURE (WT) & $53.6 \pm 3.2$ & 114.3 \\
\hline FEMALE IN BEK. STATURE (CC) & $70.0 \pm 10.9$ & $162.0^{\text {a }}$ \\
\hline FEMALE IN BEK. STATURE (WT) & $49.0 \pm 6.3$ & 140.0 \\
\hline MALE IN OBUDU STATURE (CC) & $79.0 \pm 10.3$ & 86.8 \\
\hline MALE IN OBUDU STATURE (WT) & $53.4 \pm 5.1$ & 123.5 \\
\hline FEMALE IN OBUDUSTATURE(CC) & $86.9 \pm 19.2$ & $186.8^{\mathrm{a}}$ \\
\hline FEMALE IN OBUDUSTATURE(WT) & $55.4 \pm 7.5$ & 144.7 \\
\hline
\end{tabular}

In table 4, showing Pearson's correlation shows that all chest circumference and weight measured in Bekwarra and Obudumales correlated statistically with stature

\section{DISCUSSION}

Adult males under the influence of testosterone have a significant increase in bone growth and twice the number of muscle cells of the average female (Cheek, 1974). As boys and girls advance through puberty, ratios among leg length, trunk length, and stature also change during this period. Prior to adolescence, boys have longer trunks and shorter legs than girls (Haubenstricker and Sapp, 1980). In contrast, adolescent and adult females have shorter legs for the same height than males of equal stature., there is however evidence that leg length influences upright

balance and speed Haubenstricker and Sapp, 1980. 
This corroborates with the results of table 1 and 2 of this present study where height, weight and chest circumference consistently showed sexual dimorphism. These differences between sexes are statistically significant with higher values observed in males.

In the present study, it was observed that height and weight values were constantly higher in Bekwarramales than in Bekwarra females.Higher height and weight values was also observed in Obudu, males when compared with their female counterparts in the present study.

In the present study, higher chest circumference values was observedin Obudufemalesthan Obudu males in our cohort. This larger chest circumference values in femalesmay be due to large breast and other sex chromosomes developed by females during puberty to adulthood.

Height,chest circumference and weight valuesin the present study was also observed to be significant in Obudumales and females.All measured parameters were consistently higher in Obudumales compared to Bekwarra males.The difference in linear measurements betweenthe two ethnic groups could be due to the fact that though.they both engage basically in farming of agricultural products cultivation and processing like Rice, Groundnut,Palm fruits and trading, the Obudu people are richer than the Bekwarra's.

Growth and nutrition are very much interrelated. If adequate amount of calories are not available in diet, growth of the teenager is likely to be affected hencethis variation may be due to nutritional intake between these two communities or limitation of secondary sex characteristics Chang Lee et al, (1963), Udani et al, (1963), Vashishtet al,( 2005) and MajMukharjeeet al, (2008.)

In the present study all the parameters measured in Bekwarra and Obudu males were statistically significant, the correlation coefficient between weight and chest circumference were all statistically significant and positively correlated to height, except chest circumference values of Obudu females in which negatively correlated to stature.

The present study alsoattempted to derivespecific regression equations which could help in prediction of height in males and females in Bekwarra and Obudu tribes in Cross River, Nigeria. The equation was derived as $(y=c+(m x) \pm$ standard error) where $\mathrm{y}$ is stature, $\mathrm{c}$ means standard value for measuring weight or chest circumference, $x$ means weight or chest circumference and standard error.

Each of the parameters discussed has been, and is still in use both in combination with other parameters and as independent index of health. It is important to note however that independent use of the parameters as index of health may not give the best prediction of the state of health.

This study reveals that ethnic and gender phenotypical variations with reference to chest circumference, height and weight exists between the Bekwarras andObudu's. 
It is thus hoped that results gotten from this study will be of immense use in forensic medicine and framework for anthropometric comparison of body dimension of other Nigeria ethnic groups.

\section{Aknowledgements : None}

\section{REFERENCES}

Alonso, A. (2006). Ergonomía, La Habana, Cuba.

Auyeung, T.W; Lee, J.S; Kwok, T; Leung, P.C; and Woo, J. (2009).Estimation of stature by measuring fibula and ulna bone length in 2443 older adults.J Nutr Health Aging. 2009 Dec;13(10):931-6

Chang, K.S.F; Marjorie, M; Lee, W.F; Cow and Kvan, E.C.(1963), Height and

weight of southern Chinese children. American Journal of Physical Anthropology.21, 497, 1963.

Cheek D. B.(1974).Body Composition, Hormones, Nutrition And Adolescent Growth, In:Grumbach M. M, Grave G.D Mayer F.E,eds. Control of the onset of puberty New York John Wiley and Sons :424-47

Duyer, I; Pelin, C; and Zayyapan, R. (2006). A new method of stature estimation for forensic anthropological application. Anthropological

Science International, 114, 23-27.

Ekanem, A. U. et al. (2010) 'Anthropometric study of the pinna (auricle) among adult nigerians resident in maiduguri metropolis', Journal of Medical Sciences, 10(6), pp. 176-180. doi: 10.3923/jms.2010.176.180.

Jadav, H.R; \& Shah, G. V. (2004).Determination of personal height from the length of Head in Gujarat Region. J. Anat. Soc. India, 53:20-1.

Krishan, K; and Sharma. (2007). Estimation of stature from dimension of long hand and feet bones in North Indian population. Journal of Forensic and Legal Medicine, 14:327-332.

Maj, R; Mukherjee; Lt. Col. Chaturvedi; S. Col; Bhalwar, R. (2008) Determinants of nutritional status of school children MJAFI. 64,227-231

Snell, R. S. (2012).Clinical Anatomy by Regions.9th ed. Lippincott William \& Edinburgh.2(3):50-54

Stein, P.L; Rowe, B. M; Graw Hill M. C. (1982).PhysicalAnthropometric

Edinburgh.Schieve, L.A, Cog swell, M.E, Scanlon, K.S, (2000): pregnancyBody mass index and pregnancy weight gain. 96:194-200.

Udani, P.M. (1963) Physical growth of children in different socio - economic Group's in Bombay. Indian Journalof Child Health. vol. 12-593-611

Vashisht, R. N; Kewal, Krishan, and SunitaDevtal. (2005). Physical growth and Nutritional status of Garhwali girls. Indian 
Journal Pediatric. $72 \quad$ (7): 573-578,

2005

Williams, P. L; Bannister, L. H; Berry, M. M; Collins, P; Dyson, M; Dus Gray' Anatomy. (2000). The anatomical basis of medicine and surgery. 38th Ed. New York, Churchill Livingstone.

Kanchan, T., krishan, K.,Geriani,D.,\&Khan I.S(2013) Estimation of stature from the width of static footprints-insights to an Indian model,foot,23(4),136-139.

\section{Krishan,K,Kanchan}

T.,\&Kharosha,M.A(2015),Estimation of stature from from handprint dimensionspositional variations in real crime scene situations,Egypt Journal of forensic sciences, 5, 129-131

\section{Oyewole,}

S.

\section{A.,Haight, J.M\&Freivards, A(2010).}

The ergonomic design of classroom furniture / computer work station for first graders in the elementary school. International journal of industrial ergonomics, 40, 437447.

Sharma N. anthropometric measurement and cross sectional surveying of ear pinna characteristics in northern india. J ExpClinAnat 2016;15:102-6

Deopa D., Thakkar H.K., Prakash C., Niranjan R., Barua M.P. (2013). Anthropometric measurements of external ear of medical students in Uttarakhand region. J AnatSoc India 62:79-83. .
Vicente Querol M.Á. (2015). Desarrollo de unsistema de captura de silvetas en Android. Proyecto Final de Carrera, Universidad Politécnica de Valencia. EscuelaTécnica Superior de Ingenieros de Telecomunicación.

Pate, R.; Oria, M.; Pillsbury, L. (2012). Fitness Measures and Health Outcomes in Youth. Committee on Fitness Measures and Health Outcomes in Youth; Food and Nutrition Board; Institute of Medicine. Washington (DC): National Academies Press (US). Washington (DC): National Academies Press (US); 2012 Dec 10.

Norton, K.; Olds, T. (2012). Antropometría. Anthropometrica, Edición en Español: Dr. Juan Carlos Mazzaed. University of $\mathrm{New}$ South Wales Press, Sidney 2052 Australia.

Gómez Parra, M.K. (2005). Sistemas de mediciónantropométrica para

posturassedentes

(modelofuncional). Trabajo de gradopresentadocomorequisito para optar al título de Diseñador Industrial, Universidad Industrial de Santander.

Arellano, D.; YáñezMendiola, J. (2009). MedicionesAntropométricas sin contactos a partir de fotografías. Ide@s CONCYTEG, 48, pp. 669-673.

Narváez Morales, Y. A. (2013). Ergonomía y Antropometría. MásqueCiencias. Batutas para el diseño. Revista M.A, Mueble 
Actual. Sección: Diseño de Mobiliario. Artículo: La Ergonomía II Parte.

Zaher, J. F., El-Ameen, N. F. M., \&Seedhom, A. E. (2011). Stature estimation using anthropometric measurements from computed tomography of metacarpal bones among Egyptian population. Egyptian Journal of Forensic Sciences, 1, 103-108.

Kachan T, Krishan K (2011) Anthropometry of hand in sex determination of dismembered remains-a review of literature. J of Forensic and Leg Med 18(1): 14-17.

Oria RS, Igiri AO, Egwu OA, Nandi ME (2016) Prediction of stature from hand length and breadth-anthropometric study on an adult Cross River State population. Annals of Bioanthropol 4(1): 12-16.

Haubenstricker J, Sapp M. A brief review of the Bruininks-Oseretsky test of motor proficiency. Reston, VA: National Association for Sport and Physical Education; 1980. [Reference list] 